\title{
$\mathrm{TiO}_{2}$ 의 $\mathrm{GO}$ 혼합 양에 따른 페로브스카이트 태양전지의 물성 연구
}

\author{
이혜령 · 김광배 · 송오성* \\ 서울시립대학교 신소재공학과
}

\section{Properties of Perovskite Solar Cells with GO Addition on $\mathrm{TiO}_{2}$ Layer \\ Hyeryeong Lee, Kwangbae Kim, and Ohsung Song* \\ Department of Materials Science and Engineering, University of Seoul, Seoul 02504, Republic of Korea}

\begin{abstract}
The photovoltaic properties of perovskite solar cells (PSCs) were investigated by adding graphene oxide (GO) to the electron transport layer of $\mathrm{TiO}_{2}$. The PSCs were fabricated with a glass/FTO/BL-TiO $/ \mathrm{meso}$ $\mathrm{TiO}_{2}+\mathrm{GO} /$ perovskite/HTL/Au electrode structure by adding various contents of $\mathrm{GO}$ (0.0, 0.3, 0.5 and $\left.0.7 \mathrm{wt} \%\right)$ to the $\mathrm{TiO}_{2}$ layer. To analyze the photovoltaic characteristics and transmittance of the $\mathrm{TiO}_{2}$ layer of the PSCs according to the GO content, solar simulator and ultraviolet-visible-near-infrared spectroscopy were used, respectively. Atomic force microscopy and field emission scanning electron microscope were used to analyze the microstructures of both the $\mathrm{TiO}_{2}$ layer and the perovskite layer. The results of the photovoltaic characteristics indicated that energy conversion efficiency (ECE) was gradually increased to $12.70 \%, 13.13 \%$, $14.19 \%$, and $12.63 \%$ for $0.0,0.3,0.5$, and $0.7 \mathrm{wt} \%$ GO contents, respectively. The highest ECE was observed at a GO content of $0.5 \mathrm{wt} \%$, and a decrease in the ECE was confirmed at higher levels. The increase in ECE was confirmed by measuring short circuit current density $\left(\mathrm{J}_{\mathrm{sc}}\right)$ and shunt resistance which increased with the GO addition. However, when an excessive amount of GO content was added, a decrease in the ECE was observed, due to the decrease in $\mathrm{J}_{\mathrm{sc}}$ by the reduction in transmittance. In particular, an increase in the perovskite crystal size caused an increase in the ECE, due to the increased $\mathrm{rms}$ of $\mathrm{TiO}_{2}$ at $0.5 \mathrm{wt} \% \mathrm{GO}$. With the $0.7 \mathrm{wt} \% \mathrm{GO} \mathrm{TiO}_{2}$ layer, the perovskite grain size was decreased by the reduction in rms, and this resulted in a decrease in $\mathrm{J}_{\mathrm{sc}}$ and ECE. These results suggest that we might improve the efficiency of perovskite solar cells by adding the proper amount of $\mathrm{GO}$ to the $\mathrm{TiO}_{2}$ layer.
\end{abstract}

(Received April 22, 2019; Accepted June 2, 2019)

Keywords: electron transport layer, graphene oxide, perovskite grain, AFM, perovskite solar cells

\section{1. 서 론}

페로브스카이트는 양이온과 음이온이 결합한 3차원의 결 정구조를 갖는 물질을 말하며, $\mathrm{ABX}_{3}$ 구조의 $\mathrm{A}$ 와 $\mathrm{B}$ 는 서 로 다른 양이온 $\left(\mathrm{A}=\mathrm{MA}\left(\mathrm{CH}_{3} \mathrm{NH}_{3}\right), \mathrm{FA}\left(\mathrm{CH}\left(\mathrm{NH}_{2}\right)_{2}\right), \mathrm{B}=\right.$ $\mathrm{Pb})$ 이며, $\mathrm{X}$ 는 음이온 $(\mathrm{X}=\mathrm{Br}, \mathrm{I}, \mathrm{Cl})$ 으로 이루어져 있다 [1]. 이를 채용한 태양전지는 페로브스카이트 태양전지 (perovskite solar cells; PSCs)로 2009년 약 4\%의 효율을 처음 보고한 뒤, 5 년 만에 약 $16 \%$ 의 효율이 보고되었다.

- 이혜령: 석사과정, 김광배: 박사과정, 송오성: 교수

*Corresponding Author: Ohsung Song

[Tel: +82-2-6490-5780, E-mail: songos@uos.ac.kr]

Copyright (C) The Korean Institute of Metals and Materials
또한 2019 년 현재 약 $23 \%$ 의 최고 효율이 보고되어 차세 대 태양전지로써의 연구가 활발하다 [2].

이러한 $\mathrm{PSC}$ 는 전자의 이동방향에 따라 역방향 구조와 정방향 구조로 구분이 가능하며, 역방향 구조는 glass/ transparent conducting oxide(TCO)/hole transport layer(HTL)/perovskite/electron transport layer(ETL)/metal electrode로 구성되어 있고, 정방향 구조는 glass/TCO/ETL/ perovskite/HTL/metal electrode로 구성되어 있다 [3].

역방향 구조 $\mathrm{PSC}$ 의 $\mathrm{TCO}$ 는 전기적 특성이 우수한 indium tin oxide(ITO)를 채용하고 있으며, 전자전달층 (ETL)으로 phenyl C61 butyric acid methyl ester (PCBM)을 주로 이용하고 있다 [4]. 그러나 ITO와 PCBM 은 $400{ }^{\circ} \mathrm{C}$ 이상 온도에서 전기적 특성이 변화하기 때문에 
열처리 공정의 온도를 한정해야 한다. 또한 평평한 기판 위에 페로브스카이트를 형성하기 때문에 페로브스카이트의 두께가 얇게 형성되어 기존의 $\mathrm{PSC}$ 보다 상대적으로 낮은 단락전류밀도(short circuit current density, $\mathrm{J}_{\mathrm{sc}}$ )로 인하여 낮은 에너지변환효율(energy conversion efficiency, ECE) 을 나타낸다. 따라서 역방향 구조 $\mathrm{PSC}$ 의 구조적인 문제로 인한 에너지변환효율 $(\mathrm{ECE})$ 한계로 정방향 구조 $\mathrm{PSC}$ 연구 가 활발히 이루어지고 있다.

이러한 정방향 구조 $\mathrm{PSC}$ 의 $\mathrm{TCO}$ 는 고온 열처리 공정이 가능한 fluorine doped tin oxide(FTO)를 채용하고 있으며, 전자전달층(ETL)은 mesoporous $\mathrm{TiO}_{2}$ 를 $500{ }^{\circ} \mathrm{C}$ 에서 소결 하여 사용하고 있다 [5]. 이때 mesoporous $\mathrm{TiO}_{2}$ 는 페로브 스카이트가 형성되는 뼈대로 작용하여 두꺼운 페로브스카 이트 형성이 가능하다 [6]. 두꺼운 페로브스카이트 층으로 인하여 정방향 구조 $\mathrm{PSC}$ 에서 상대적으로 높은 단락전류 밀도 $\left(\mathrm{J}_{\mathrm{sc}}\right)$ 로 인한 우수한 에너지변환효율 $(\mathrm{ECE})$ 이 보고되고 있다.

그러나 $\mathrm{TiO}_{2}$ 의 경우, oxide 물질로 전기저항이 높은 문 제를 가지고 있으며 [7], 이를 개선하기 위해 $\mathrm{TiO}_{2}$ 대체 물질을 사용하거나 $\mathrm{TiO}_{2}$ 에 탄소계 물질을 혼합한 연구가 활발하다. $\mathrm{Liu}$ 등[8]은 $\mathrm{TiO}_{2}$ 대신 $\mathrm{SnO}_{2}$ 를 재결합방지층 및 전자전달층(ETL)으로 채용하였으며, 이는 기계적 안정성과 화학적 안정성이 향상되어 공기 중의 습도에 의한 페로브 스카이트의 열화를 방지하고, 소자 수명을 3000시간 이상 향상시킨 결과를 보고한 바 있다. 그러나 $\mathrm{SnO}_{2}$ 를 전자전 달층(ETL)으로 채용한 소자의 경우, 기존 $\mathrm{TiO}_{2}$ 층은 30 분 만에 제작이 가능한 반면, $\mathrm{SnO}_{2}$ 층을 형성하는데 4시간이 소요되어 장시간 공정이 필요한 문제가 있었다.

Bati 등[9]은 $\mathrm{TiO}_{2}$ 에 탄소계 물질인 s-SWCNT와 m$\mathrm{SWCNT}$ 를 혼합하여 전자전달층(ETL)으로 채용하였으며, 이때 s-SWCNT는 반도체 성질을 나타내고, m-SWCNT는 금속 성질을 나타낸다. 이러한 성질을 이용하여 s-SWCNT 와 m-SWCNT를 2:1 비율로 $\mathrm{TiO}_{2}$ 와 혼합하여 향상된 단 락전류밀도 $\left(\mathrm{J}_{\mathrm{sc}}\right)$ 와 개방전압(voltage open circuit; $\left.\mathrm{V}_{\mathrm{oc}}\right)$ 을 통 해 $19.35 \%$ 의 에너지변환효율(ECE)을 갖는 $\mathrm{PSC}$ 를 보고한 바 있다. 그러나 성질이 다른 두 종류의 SWCNT는 재료 의 적정비를 도출하는 과정에서 시간과 비용이 많이 소요 되는 문제가 있었다.

Han 등[10]은 $0.4 \mathrm{vol} \%$ 의 reduced graphene oxide(rGO) 를 mesoporous $\mathrm{TiO}_{2}$ 에 혼합하여 소자의 계면 저항을 줄 이고 전기전도도를 향상시켜 기존 소자보다 효율이 $17.39 \%$ 증가된 $13.50 \%$ 의 에너지변환효율 $(\mathrm{ECE})$ 을 갖는 $\mathrm{PSC}$ 를 보고한 바 있다. 그러나 $\mathrm{rGO}$ 를 채용할 경우, $\mathrm{rGO}$
제작 기간만 5일 이상의 시간이 소요되기 때문에 PSC 제 작 공정시간이 증가하는 문제가 있었다.

이와 같이 정방향 구조 $\mathrm{PSC}$ 의 효율을 높이기 위한 연구 로는 전자전달층 $(\mathrm{ETL})$ 의 $\mathrm{TiO}_{2}$ 를 대체하거나 탄소계 재료 를 혼합한 연구가 보고되고 있으나, 아직까지 graphene oxide $(\mathrm{GO})$ 를 혼합하여 이들의 광전기적 특성 및 혼합된 전자전달층(ETL)과 상부 페로브스카이트 층의 미세구조 변 화를 비교한 연구는 보고된 바 없다.

따라서, 본 연구에서는 정방향 구조 PSC의 mesoporous $\mathrm{TiO}_{2}$ 에 수용액 상태인 $\mathrm{GO}$ 를 각각 $0.0,0.3,0.5,0.7 \mathrm{wt} \%$ 혼합하여 전자전달층(ETL)을 제작하고, 혼합된 $\mathrm{GO}$ 양에 따른 $\mathrm{PSC}$ 의 광전기적 특성과 미세구조의 영향을 확인하고 자 하였다.

\section{2. 실험방법}

본 연구에서는 $\mathrm{GO}$ 수용액 혼합 양에 따른 $\mathrm{PSC}$ 의 물성 을 확인하기 위해 그림 1 (a)에 나타낸 바와 같이 glass/ FTO/BL-TiO $/$ /meso-TiO $2+\mathrm{GO} /$ perovskite/HTL/Au electrode 구조의 PSC를 제작하였으며, (b)에는 최종적으로 제작한 소자의 실제 모습을 나타내었다.

이러한 소자를 구현하기 위해 세척된 glass/FTO 기판 위에 compact $\mathrm{TiO}_{2}(\mathrm{SC}-\mathrm{BT} 060$, Sharechem) 용액을 이용 하여 재결합방지층 $\left(\mathrm{BL}-\mathrm{TiO}_{2}\right)$ 을 제작하였다. Mesoporous $\mathrm{TiO}_{2}$ 는 $3.5 \mathrm{~g}$ 프로판올, $1 \mathrm{~g}$ 테르피네올을 혼합한 용액 $4 \mathrm{~g}$ 과 $1 \mathrm{~g} \mathrm{TiO}_{2}$ 페이스트(Sharechem)를 혼합하여 제작하였으 며, $\mathrm{TiO}_{2}$ 페이스트 $1 \mathrm{~g}$ 을 기준으로 각각 $0.3,0.5,0.7 \mathrm{wt} \%$ $\mathrm{GO}$ 수용액을 혼합하였다. 이때 GO 수용액(GRAPHENE SUPERMARKET Co)은 $0.5 \sim 5 \mu \mathrm{m}$ 크기의 그래핀 플레 이크(graphene flake)가 $5 \mathrm{~g} / \mathrm{L}$ 농도로 혼합된 용액을 사용 하였다. 준비한 용액들을 기판에 스핀코팅하고 소결하여 meso- $\mathrm{TiO}_{2}$ 층을 형성하였다.

페로브스카이트 용액은 $\mathrm{MAI}\left(\mathrm{CH}_{3} \mathrm{NH}_{3} \mathrm{I}, 99 \%\right.$, Dyesol), $\mathrm{PbI}_{2}$ (99.99\%, Alfa Aesar), DMSO (Dimethyl sulfoxide, sigma aldrich)를 DMF (dimethyl formamide, Alfa Aesar)에 혼합하여 제작하였다. 준비된 용액을 스핀코팅 후 핫플레이트에 연속적으로 $70^{\circ} \mathrm{C}-1 \mathrm{~min}, 100{ }^{\circ} \mathrm{C}-10 \mathrm{~min}$ 열처리하여 페로브스카이트 박막을 형성하였다. 정공전달 층(HTL)은 spiro-MeOTAD(Sigma aldrich), Li-TFSI solution(520 mg Li-TSFI(Sigma aldrich) in $1 \mathrm{ml}$ acetonitrile(Sigma aldrich)), 4-tert-buthyl pyridine(Sigma aldrich)를 클로로벤젠에 혼합하여 제작하였다. 이후 진공증 착기를 이용하여 $0.8 \AA \mathrm{A} / \mathrm{s}$ 속도로 $80 \mathrm{~nm} \mathrm{Au}$ 전극을 증착 
(a)

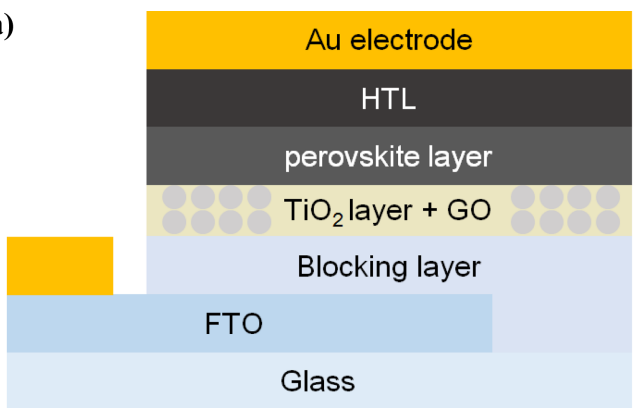

(b)

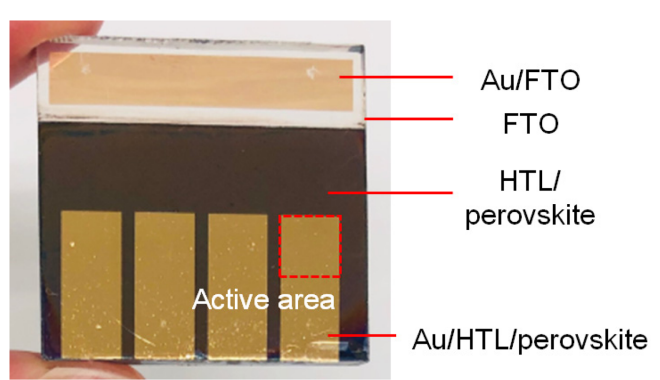

Fig. 1. (a) Illustration of the cross sectional structure of the proposed perovskite solar cell, and (b) an optical-image of a perovskite solar cell.
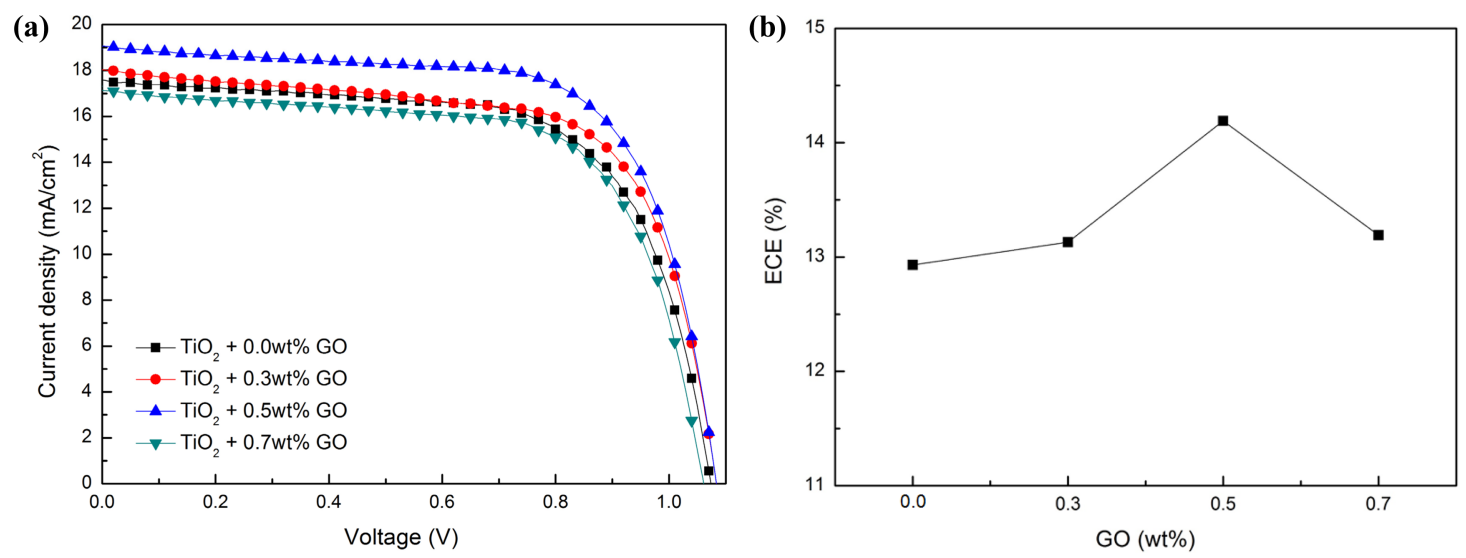

Fig. 2. (a) Current density-voltage graph, and (b) ECE change with GO addition.

하여, 최종적으로 glass/FTO/BL- $\mathrm{TiO}_{2} / \mathrm{meso}^{-\mathrm{TiO}_{2}}+\mathrm{GO} /$ perovskite/HTL/Au electrode 구조의 PSC를 제작하였다 [11].

제작한 $\mathrm{PSC}$ 의 광전기적 특성을 확인하기 위해 solar simulator(PEC-L11, Peccell)와 potentiostat(CompactStat, Ivium)을 이용하여 I-V(current-voltage)를 측정하였다. 이때 광원은 $100 \mathrm{~W}$ Xenon lamp를 이용하고, $1 \mathrm{sun}(100 \mathrm{~mW} /$ $\mathrm{cm}^{2}$ ) 조건으로 분석하였다. I-V 분석을 통해 단락전류밀도 $\left(\mathrm{J}_{\mathrm{sc}}\right)$, 개방전압 $\left(\mathrm{V}_{\mathrm{oc}}\right)$, 필팩터(fill factor; $\left.\mathrm{FF}\right)$, 에너지변환효율 $(\mathrm{ECE})$ 을 확인하였다. 또한 $\mathrm{I}-\mathrm{V}$ 그래프의 $\mathrm{y}$ 축에 인접한 부 분의 기울기를 통해 션트저항(shunt resistance; $\mathrm{R}_{\mathrm{sh}}$ )을 확 인하였다 [12].

전자전달층(ETL)의 투과도를 확인하기 위해 UV-VISNIR(UV-3101PC, Shimadzu)를 이용하였으며, 400 800 $\mathrm{nm}$ 의 가시광선 영역에서 확인하였다.

$\mathrm{GO}$ 혼합 양에 따른 $\mathrm{PSC}$ 의 전자전달층(ETL)과 페로브 스카이트의 표면 미세구조를 분석하기 위해 $\mathrm{FE}-\mathrm{SEM}(\mathrm{S}-$ 4300 , Hitachi)을 이용하였으며, 이때 가속전압은 $5 \mathrm{kV}$ 로 분석하였다.

전자전달층(ETL)의 표면 조도를 분석하기 위해 $\mathrm{AFM}$ (XE-100, PSIA Co)을 이용하였으며, non-contact mode로
시편의 root mean square(rms)를 분석하였다.

\section{3. 실험결과}

그림 2에는 $\mathrm{GO}$ 혼합 양을 달리하여 제작한 $\mathrm{PSC}$ 소자 의 I-V 그래프와 에너지변환효율 $(\mathrm{ECE})$ 변화 그래프를 나 타내었다. (a)에는 인가전압에 따른 전류밀도를 나타내었다 . 각 측정 그래프를 통해 주어진 조건에서의 단락전류밀도 $\left(\mathrm{J}_{\mathrm{sc}}\right)$, 개방전압 $\left(\mathrm{V}_{\mathrm{oc}}\right)$, 필팩터 $(\mathrm{FF})$, 에너지변환효율 $(\mathrm{ECE})$ 까지 확인할 수 있었으며, $0.5 \mathrm{wt} \% \mathrm{GO}$ 일 때 에너지변환효율 $(\mathrm{ECE})$ 이 가장 우수한 것을 확인하였다.

(b)에는 (a)의 에너지변환효율(ECE) 변화를 나타내었다. $0.5 \mathrm{wt} \% \mathrm{GO}$ 에서 $\mathrm{GO}$ 가 혼합되지 않은 소자에 비해 $11.73 \%$ 증가된 에너지변환효율(ECE)을 확인할 수 있었으 며, $0.7 \mathrm{wt} \% \mathrm{GO}$ 가 혼합된 소자에서 $\mathrm{GO}$ 를 혼합하지 않은 소자와 유사한 에너지변환효율(ECE)을 확인할 수 있었다. 따라서 기존 연구의 $\mathrm{TiO}_{2}$ 혼합과 같이 적정한 $0.5 \mathrm{wt} \%$ $\mathrm{GO}$ 를 혼합한 소자에서 에너지변환효율 $(\mathrm{ECE})$ 이 가장 우수 한 것을 확인하였으며, 이후 $0.7 \mathrm{wt} \% \mathrm{GO}$ 를 혼합 시 에너 지변환효율 $(\mathrm{ECE})$ 이 감소하는 현상을 확인하였다. 
Table 1. Photovoltaic properties of PSCs with GO addition.

\begin{tabular}{cccccc}
\hline $\begin{array}{c}\text { GO content } \\
(\text { wt } \%)\end{array}$ & $\begin{array}{c}\mathrm{J}_{\mathrm{sc}} \\
\left(\mathrm{mA} / \mathrm{cm}^{2}\right)\end{array}$ & $\begin{array}{c}\mathrm{V}_{\mathrm{oc}} \\
(\mathrm{V})\end{array}$ & $\mathrm{FF}$ & $\begin{array}{c}\mathrm{R}_{\text {sh }} \\
\left(\Omega \mathrm{cm}^{2}\right)\end{array}$ & $\begin{array}{c}\mathrm{ECE} \\
(\%)\end{array}$ \\
\hline 0.0 & 17.45 & 1.07 & 0.68 & 5797.77 & 12.70 \\
\hline 0.3 & 18.02 & 1.08 & 0.68 & 5789.38 & 13.13 \\
\hline 0.5 & 19.05 & 1.08 & 0.69 & 6921.17 & 14.19 \\
\hline 0.7 & 17.54 & 1.06 & 0.68 & 5583.29 & 12.63 \\
\hline
\end{tabular}

표 1 에는 그림 2 에 나타낸 각 물성 분석 결과를 자세히 나타내었다. 단락전류밀도 $\left(\mathrm{J}_{\mathrm{sc}}\right)$ 의 경우, $\mathrm{GO}$ 혼합 양 0.0 , $0.3,0.5,0.7 \mathrm{wt} \%$ 에 따라 각각 $17.45,18.02,19.05$, $17.54 \mathrm{~mA} / \mathrm{cm}^{2}$ 로 확인되었다. $0.5 \mathrm{wt} \% \mathrm{GO}$ 의 경우, $\mathrm{GO}$ 가 혼합되지 않은 소자에 비해 $9.16 \%$ 증가된 단락전류밀 도 $\left(\mathrm{J}_{\mathrm{sc}}\right)$ 를 확인할 수 있었으며, $0.7 \mathrm{wt} \% \mathrm{GO}$ 의 경우, $\mathrm{GO}$ 를 혼합하지 않은 소자와 유사한 단락전류밀도 $\left(\mathrm{J}_{\mathrm{sc}}\right)$ 를 확인 할 수 있었다.

개방전압 $\left(\mathrm{V}_{\mathrm{oc}}\right)$ 과 필팩터( $\left.\mathrm{FF}\right)$ 의 경우, 모두 오차 범위 내 에서 유사한 값이 확인되어, $\mathrm{GO}$ 에 따른 큰 변화는 없는 것으로 판단하였다.

션트저항 $\left(\mathrm{R}_{\mathrm{sh}}\right)$ 의 경우, $0.5 \mathrm{wt} \% \mathrm{GO}$ 가 혼합된 소자에서 가장 우수한 션트저항 $\left(\mathrm{R}_{\mathrm{sh}}\right)$ 값을 확인할 수 있었다. 이는 전 기전도도가 우수한 $\mathrm{GO}$ 가 혼합됨에 따라 전자전달층(ETL) 의 저항이 감소하여 나타난 현상으로 판단하였으며, 0.7 $\mathrm{wt} \% \mathrm{GO}$ 가 혼합된 소자에서 감소한 션트저항 $\left(\mathrm{R}_{\mathrm{sh}}\right)$ 값은 과 량의 $\mathrm{GO}$ 혼합으로 나타난 현상으로 판단하였다.

에너지변환효율 $(\mathrm{ECE})$ 의 경우, $\mathrm{GO}$ 혼합 양 $0.0,0.3$, $0.5,0.7 \mathrm{wt} \%$ 에 따라 각각 $12.70,13.13,14.19,12.63 \%$ 로 단락전류밀도 $\left(\mathrm{J}_{\mathrm{sc}}\right)$, 션트저항 $\left(\mathrm{R}_{\mathrm{sh}}\right)$ 과 비슷한 경향성을 가 지고 증가하다 감소하는 특성을 보였다. 특히 $0.5 \mathrm{wt} \%$ $\mathrm{GO}$ 의 경우, $\mathrm{GO}$ 가 혼합되지 않은 소자에 비해 $11.73 \%$ 증 가된 가장 큰 에너지변환효율 $(\mathrm{ECE})$ 을 확인할 수 있었다. 이는 $\mathrm{TiO}_{2}$ 보다 상대적으로 전기전도도가 우수한 $\mathrm{GO}$ 가 혼 합됨으로써 전자전달층(ETL)의 자체 저항이 감소하였으며, 이로 인한 션트저항 $\left(\mathrm{R}_{\mathrm{sh}}\right)$ 의 증가로 단락전류밀도 $\left(\mathrm{J}_{\mathrm{sc}}\right)$ 가 변 화하여 나타난 현상으로 판단하였다. 이러한 단락전류밀도 $\left(\mathrm{J}_{\mathrm{sc}}\right)$ 와 션트저항 $\left(\mathrm{R}_{\mathrm{sh}}\right)$ 의 개선을 통한 에너지변환효율 $(\mathrm{ECE})$ 의 증가는 $\mathrm{Yao}$ 등[13]이 $\mathrm{VO}_{\mathrm{x}}$ 에 $\mathrm{Ce}$ 을 도핑 시켜 전도성 이 향상될 경우, 기존 소자 보다 전자이동도가 향상되어 단락전류밀도 $\left(\mathrm{J}_{\mathrm{sc}}\right)$ 와 션트저항 $\left(\mathrm{R}_{\mathrm{sh}}\right)$ 의 증가로 인한 에너지변 환효율(ECE)이 증가한다는 보고와 일치하였다. 따라서, $\mathrm{GO}$ 가 혼합됨에 따라 단락전류밀도 $\left(\mathrm{J}_{\mathrm{sc}}\right)$ 의 변화를 확인할 수 있었고, 이는 에너지변환효율(ECE)의 변화에 직접적인 영 향을 미치는 것으로 판단하였다.

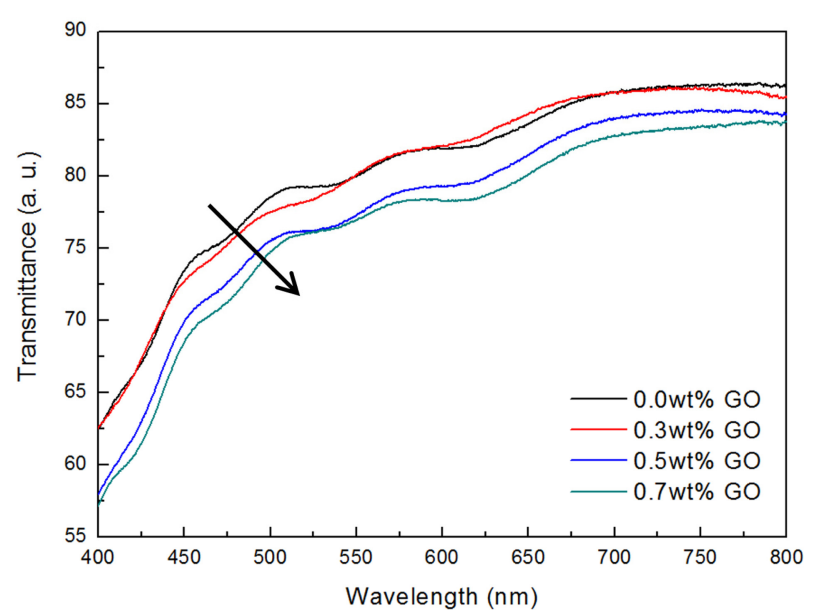

Fig. 3. Transmittance data of ETL with GO addition.

한편, $0.7 \mathrm{wt} \% \mathrm{GO}$ 의 경우, 에너지변환효율 $(\mathrm{ECE})$ 이 감소 하여 $\mathrm{GO}$ 를 혼합하지 않은 소자와 유사한 에너지변환효율 (ECE)을 보였다. 이러한 과량의 물질 첨가에 따른 에너지 변환효율 $(\mathrm{ECE})$ 의 감소는 $\mathrm{Han}$ 등[10]이 $\mathrm{TiO}_{2}$ 층에 $\mathrm{rGO}$ 를 과량 첨가하게 되면 투과도가 감소하여 결국 전류생성량이 감소하여 단락전류밀도 $\left(\mathrm{J}_{\mathrm{sc}}\right)$ 가 감소하게 되고, 단락전류밀도 $\left(\mathrm{J}_{\mathrm{sc}}\right)$ 의 감소는 에너지변환효율 $(\mathrm{ECE})$ 의 감소로 나타나는 현 상과 잘 일치하였다.

그림 3에는 $\mathrm{GO}$ 혼합에 따른 전자전달층(ETL)의 투과도 분석 결과를 나타내었다. 투과도 분석 결과에 화살표로 표 시한 방향과 같이 $\mathrm{GO}$ 의 혼합 양이 증가됨에 따라 시편의 투과도는 전반적으로 감소하는 것을 확인할 수 있었다. 특 히 $0.7 \mathrm{wt} \% \mathrm{GO}$ 를 혼합한 경우의 투과도는 가시광선 영 역에서 $\mathrm{GO}$ 가 혼합되지 않은 시편 대비 약 $4 \%$ 가 감소되 는 것을 확인할 수 있었으며, 이는 앞서 표 1 에서 보인 단락전류밀도 $\left(\mathrm{J}_{\mathrm{sc}}\right)$, 에너지변환효율 $(\mathrm{ECE})$ 감소의 직접적인 원인으로 판단하였다.

이러한 투과도 감소는 페로브스카이트에 도달하는 빛 에 너지의 감소를 의미하고, 이에 따라 단락전류밀도 $\left(\mathrm{J}_{\mathrm{sc}}\right)$ 가 감 소한 것으로 판단하였다. 이는 $\mathrm{Kim}$ 등[14]이 기존의 채용 되던 $\mathrm{TCO}$ 를 대신하여 $\mathrm{Ag}$ nanowire와 그래핀을 이용한 
(a)

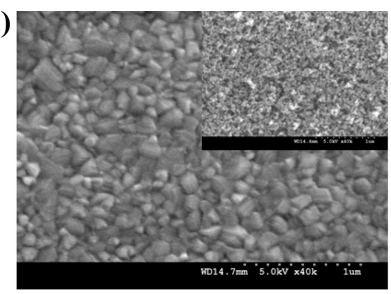

(c)

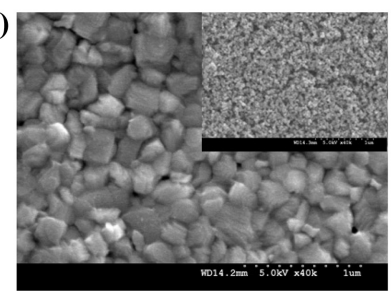

Fig. 4. FE-SEM images of perovskite layer with GO content of (a) $0.0 \mathrm{wt} \%$, (b) $0.3 \mathrm{wt} \%$, (c) $0.5 \mathrm{wt} \%$, and (d) $0.7 \mathrm{wt} \%$. Insets show meso- $\mathrm{TiO}_{2}$ underlayers.

전극을 제안하고, $\mathrm{Ag}$ nanowire의 첨가량이 증가함에 따라 전기적 특성은 증가하였지만 투과도가 감소하는 것을 확인 하였으며, 이는 전류밀도가 감소한다고 보고한 바와 일치 하는 결과였다.

따라서, $\mathrm{GO}$ 혼합 양이 증가함에 따라 투과도가 점차 감 소하고, 이에 따라 단락전류밀도 $\left(\mathrm{J}_{\mathrm{sc}}\right)$ 가 감소하는 것을 확인 하였다.

그림 4에는 $\mathrm{GO}$ 혼합에 따른 페로브스카이트의 표면 미 세구조를 나타내었다. 우상단에 나타낸 $\mathrm{meso}^{-\mathrm{TiO}_{2}}$ 층의 표 면 이미지는 모두 비슷함에도 불구하고 페로브스카이트 결 정립 크기 변화가 있음을 확인하였다.

(a)는 $\mathrm{GO}$ 가 혼합되지 않은 전자전달층(ETL) 위에 형성 된 페로브스카이트 표면으로 결정립 크기가 약 $184 \mathrm{~nm}$ 로 형성된 것을 확인하였다. (b)는 $0.3 \mathrm{wt} \% \mathrm{GO}$ 가 혼합된 경 우의 페로브스카이트 표면으로, 결정립 크기가 약 $210 \mathrm{~nm}$ 로 형성되어 (a)보다 $14.13 \%$ 증가된 결정립 크기를 보였 다. (c)는 $0.5 \mathrm{wt} \% \mathrm{GO}$ 가 혼합된 경우로, 결정립은 약 $245 \mathrm{~nm}$ 로 형성되어 (a)보다 $33.15 \%$ 증가된 것을 확인하였 다. (d)는 $0.7 \mathrm{wt} \% \mathrm{GO}$ 가 혼합된 경우로, 결정립 크기가 약 $191 \mathrm{~nm}$ 로 감소하였다.

이러한 하부의 meso- $\mathrm{TiO}_{2}$ 층의 표면구조가 비교적 비슷 하더라도 $\mathrm{GO}$ 와 같은 첨가제에 의해 상부의 페로브스카이 트 층의 결정립 크기가 변화할 수 있는 사실은 $\mathrm{Cai}$ 등 [15]이 $\mathrm{TiO}_{2}$ 에 적정량의 $\mathrm{Sn}$ 을 도핑시킨 전자전달층(ETL) 을 채용하여 기존 $\mathrm{TiO}_{2}$ 를 채용한 소자보다 페로브스카이 트 결정립 크기가 1.8 배 증가한 것을 보고한 바와 일치함 을 보였다. Hsieh 등[16]은 페로브스카이트 결정립 크기가 증가하면 광전효과로 발생된 전자와 정공의 이동 저항으로

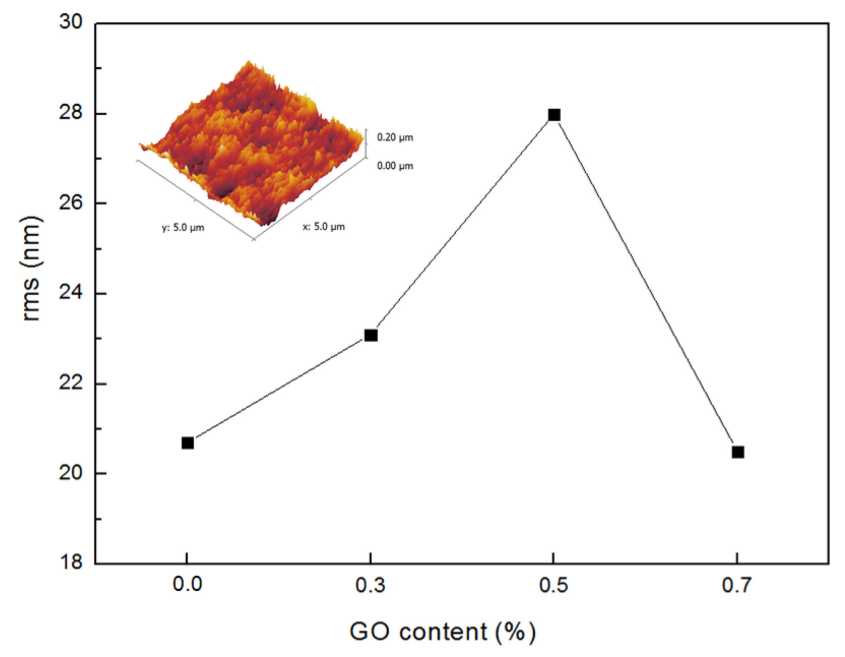

Fig. 5. Surface roughness data of meso- $\mathrm{TiO}_{2}$ layer with $\mathrm{GO}$ addition.

작용하는 결정립계가 상대적으로 감소하여 결국 전자와 정 공의 이동성이 향상되어 에너지변환효율 $(\mathrm{ECE})$ 이 증가하는 메커니즘을 보고한 바 있다.

따라서 $0.5 \mathrm{wt} \% \mathrm{GO}$ 시편의 에너지변환효율(ECE) 증가 와 다시 $0.7 \mathrm{wt} \% \mathrm{GO}$ 시편의 감소는 이러한 $\mathrm{GO}$ 혼합에 따른 페로브스카이트 층의 미세구조 변화도 한 원인일 수 있었다.

그림 5 에는 $\mathrm{GO}$ 혼합 양에 따른 전자전달층 $(\mathrm{ETL})$ 의 $\mathrm{rms}$ 변화를 $\mathrm{AFM}$ 으로 분석하여 나타내었다. $\mathrm{GO}$ 혼합 양 $0.0,0.3,0.5,0.7 \mathrm{wt} \%$ 에 따른 $\mathrm{rms}$ 는 각각 $20.7 \mathrm{~nm}, 23.1$ $\mathrm{nm}, 28.0 \mathrm{~nm}, 20.5 \mathrm{~nm}$ 로 확인되었으며, $0.5 \mathrm{wt} \% \mathrm{GO}$ 를 혼합한 소자에서 가장 거친 $\mathrm{rms}$ 값을 확인하였다. 이러한 $\mathrm{rms}$ 의 변화는 구형으로 구성된 $\mathrm{meso}-\mathrm{TiO}_{2}$ 에 플레이크 형 태의 GO가 혼합됨에 따라 나타난 현상으로 판단하였으며, 이는 Morlta 등[17]이 서로 다른 형상을 가진 두 물질을 혼합할 때 특정 비율에서 가장 거친 $\mathrm{rms}$ 를 보고한 바와 일치하는 결과였다.

또한 $\mathrm{rms}$ 변화는 앞서 확인한 미세구조 결과에서 페로 브스카이트 결정립 크기에 영향을 미치는 것을 확인할 수 있었으며, 하부 $\mathrm{rms}$ 변화에 따른 상부 페로브스카이트 결 정립 크기는 Shi 등[18]이 동일한 구조에서 하부 기판이 거친 시편, 즉 $\mathrm{rms}$ 값이 큰 시편이 $\mathrm{rms}$ 값이 작은 시편 보다 페로브스카이트 결정립 크기가 약 2배 증가한 것을 보고한 바와 일치하는 결과였다. 이러한 하부 기판의 $\mathrm{rms}$ 가 페로브스카이트 결정립 크기에 영향을 미치는 메커니즘 은 $\mathrm{Li}$ 등[19]이 요철 모양의 골 부분에서 핵 생성 사이트 가 형성되기 쉬우며, $\mathrm{rms}$ 는 핵 생성 사이트의 간격을 결정 
하여 페로브스카이트 결정립 크기를 결정하는 중요한 역할 을 한다고 보고한 바 있다. 페로브스카이트 결정립 크기의 증가는 결정립계의 감소를 의미하며, 결정립계는 전자이동 과 정공이동을 방해하는 저항으로 작용하기 때문에 결정립 크기의 증가는 내부 저항을 감소시켜 최종적으로 에너지변 환효율 $(\mathrm{ECE})$ 을 향상시킬 수 있었다.

따라서 전자전달층 $(\mathrm{ETL})$ 에 적정한 $\mathrm{GO}$ 혼합 시 전자전 달층 $(\mathrm{ETL})$ 의 $\mathrm{rms}$ 가 증가하고, 이는 페로브스카이트 결정 립 크기에 영향을 미쳐 결정립계가 감소하여, 최종적으로 에너지변환효율 $(\mathrm{ECE})$ 이 증가함을 확인할 수 있었다.

\section{4. 결 론}

전자전달층(ETL)에 $\mathrm{GO}$ 수용액을 혼합하여 에너지변환 효율 $(\mathrm{ECE})$ 이 향상된 $\mathrm{PSC}$ 를 성공적으로 제작하였다. $\mathrm{GO}$ 혼합 양이 증가함에 따라 $0.5 \mathrm{wt} \% \mathrm{GO}$ 에서 최대 에너지변 환효율(ECE)을 확인하였으며, 과량의 $\mathrm{GO}$ 혼합 시 에너지 변환효율 $(\mathrm{ECE})$ 이 감소되는 것을 확인하였다. 이러한 에너 지변환효율(ECE)의 변화는 $0.5 \mathrm{wt} \% \mathrm{GO}$ 혼합까지는 전도 성이 우수한 $\mathrm{GO}$ 가 전자이동을 도와 단락전류밀도 $\left(\mathrm{J}_{\mathrm{sc}}\right)$ 와 션 트저항 $\left(\mathrm{R}_{\mathrm{sh}}\right)$ 을 증가시켰기 때문이고, $0.7 \mathrm{wt} \% \mathrm{GO}$ 에서 에너 지변환효율 $(\mathrm{ECE})$ 의 감소는 전자전달층 $(\mathrm{ETL})$ 의 투과도 감 소로 인한 빛 총량이 감소하여 광전기적 특성이 감소하는 것을 확인하였다. 또한 미세구조 분석을 통해 $\mathrm{GO}$ 혼합에 따른 전자전달층 $(\mathrm{ETL})$ 의 $\mathrm{rms}$ 변화는 상부 페로브스카이트 층에 영향을 미쳐 페로브스카이트 결정립 크기를 증가시켰 으며, 이는 결정립계를 감소시켜 에너지변환효율(ECE) 증 가의 한 원인일 수 있었다. 따라서 $\mathrm{PSC}$ 의 전자전달층 $(\mathrm{ETL})$ 에 $\mathrm{GO}$ 를 혼합할 시 단락전류밀도 $\left(\mathrm{J}_{\mathrm{sc}}\right)$, 투과도, 그리 고 페로브스카이트 결정립 크기를 고려한 적절한 양의 $\mathrm{GO}$ 채용이 필요하였다.

\section{ACKNOWLEDGEMENT}

This research was supported by Basic Science Research Program through the National Research Foundation of Korea(NRF) funded by the Ministry of Education (2017R1D1A1B03029347).

\section{REFERENCES}

1. M. A. Green, A. H. Baillie, and H. J. Snaith, Nat. Photonics 8, 506 (2014).

2. F. Xiea, J. Zhua, Y. Lia, D. Shena, A. Abateb, and M. Wei, J. Power Sources 415, 8 (2019).

3. S. S. Mali and C. K. Hong, Nanoscale 8, 10528 (2016).

4. J. Chang, H. Zhu, J. Xiao, F. H. Isikgor, Z. Lin, Y. Ha, K. Zeng, Q. H. Xu, and J. Ouyang, J. Mater. Chem. A 4, 7943 (2016).

5. M. A. Jalebi, M. I. Dar, A. Sadhanala, S. P. Senanayak, M. Gratzel, and R. H. Friend, J. Vis. Exp. 121, e55307 (2017).

6. A. M. Adams, J. M. M. Beloqui, G. Stoica, and E. Palomares, J. Mater. Chem. A 3, 22154 (2015).

7. S. L. Fernandes, L. G. S. Albano, L. J. Affonco, J. H. D. Silva, E. Longo, and C. F. O. Graeff, Front Chem. 7, 50 (2019).

8. Q. Liu, M. C. Qin, W. J. Ke, X. L. Zheng, Z. Chen, P. L. Qin, L. B. Xiong, H. W. Lei, J. W. Wan, J. Wen, G. Yang, J. J. Ma, Z. Y. Zhang, and G. J. Fang, Adv. Funct. Mater. 26, 6069 (2016).

9. A. S. R. Bati, L. P. Yu, S. A. Tawfik, M. J. S. Spencer, P. E. Shaw, M. Batmunkh, and J. G. Shapter, iScience, (In press).

10. G. S. Han, Y. H. Song, Y. U. Jin, J. W. Lee, N. G. Park, B. K. Kang, J. K. Lee, I. S. Cho, D. H. Yoon, and H. S. Jung, ACS Appl. Mater. Inter. 7, 23521 (2015).

11. K. Kim, T. Park, and O. Song, Korean J. Met. Mater. 56, 321 (2018).

12. C. Honsberg and S. Bowden, PV CDROM, http:// www.pveducation.org/pvcdrom (2019).

13. X. Yao, J. Qi, W. Xu, X. Jiang, X. Gong, and Y. Cao, ACS Omega 3, 1117 (2018).

14. S. Kim, S. H. Shin, and S. H. Choi, J. Alloy. Compd. 786, 614 (2019).

15. Q. Cai, Y. Zhang, C. Liang, P. Li, H. Gu, X. Liu, J. Wang, Z. Shentu, J. Fan, and G. Shao, Electrochim. Acta 261, 227 (2018).

16. C. M. Hsieh, Y. S. Liao, Y. R. Lin, C. P. Chen, C. M. Tsai, E. W. G. Diaua, and S. C. Chuang, RSC Adv. 8, 19610 (2018).

17. H. Morlta and M. Doi, J. Micro-Nanolith. Mem. 9, 041213 (2010).

18. B. Shi, B. Liu, J. Luo, Y. Li, C. Zheng, X. Yao, L. Fan, J. Liang, Y. Ding, C. Wei, D. Zhang, Y. Zhao, and X. Zhang, Sol. Energ. Mat. Sol. C. 168, 214 (2017).

19. Y. Li, B. Ding, Q. Q. Chu, G. J. Yang, M. Wang, C. X. Li, and C. J. Li, Sci. Rep. 7, 46141 (2017). 